\title{
Variations in the Plasma Levels of Thyroid Hormones and Testicular Activity in the Male Air-breathing Catfish (Clarias gariepinus) over the Annual Cycle
}

\author{
P Suchiang \\ Environmental Endocrinology Laboratory \\ Department of Zoology, North-Eastern Hill University \\ Shillong - 793022, Meghalaya, India \\ Present Address: Department of Zoology, Tura Govt. College, Tura \\ Meghalaya - 794001, India \\ E-mail: pfmsng@gmail.com \\ B B P Gupta \\ Environmental Endocrinology Laboratory \\ Department of Zoology, North-Eastern Hill University \\ Shillong - 793022, Meghalaya, India
}

Received: February 14, 2011 Accepted: April 30, 2011 doi:10.5539/ijb.v3n3p144

\begin{abstract}
The purpose of this study is to evaluate seasonal variations in thyroxine $\left(\mathrm{T}_{4}\right)$ and triiodothyronine $\left(\mathrm{T}_{3}\right)$ levels and testicular activity in the male air-breathing catfish Clarias gariepinus. Plasma $\mathrm{T}_{4}$ levels increased from March to a peak in July and then decreased throughout autumn, declining to their lowest level in January. Plasma $T_{3}$ levels also varied seasonally, increasing from March to a peak in June. The increase in plasma levels of thyroid hormones coincided with an increase in the testicular activity of the fish. The gonadosomatic index (GSI) peaked in May and then declined slowly. In February and March, the testes were characterized by a new generation of spermatogenic cells. Mature spermatozoa appeared in April and became dominant in the testes during the summer months. Testicular activity decreased gradually with the gradual decrease in water temperature and day-length during the autumn season. Decreased testicular activity during the winter months was associated with low GSI values. The patterns of seasonal change in the levels of thyroid hormones as well as testicular activity were similar to those in water temperature and natural day-length.
\end{abstract}

Keywords: Thyroid hormone, Thyroxine, Triiodothyronine, Testicular activity, Catfish, Clarias gariepinus

\section{Introduction}

Many fish species exhibit cyclical variations in plasma levels of thyroid hormones that are associated with sexual maturation (Cyr et al., 1998; Eales, 2006; Pavlidis et al., 2000), breeding cycle (Eales, 2006; Supriya et al., 2005; Volkoff et al., 1999), the regulation of oxidative metabolism (Gupta and Thapliyal, 1991; Lynshiang and Gupta, 2000; Peter and Oommen, 1987), migration (Imbert et al., 2008; Iwata, 1995; Ojima and Iwata, 2007), electrolyte and water metabolism (Klaren et al., 2005; Peter et al., 2000), and so on. These hormones help the fish continually adjust their physiological and morphological characteristics in relation to the ever-changing aquatic environment (Eales, 2006; Matty, 1985). The environmental cycles of photoperiod, temperature, and rainfall seem to provide predictive information and act as indicators of seasons for fish (Andrade and Braga, 2005; Malhotra et al., 1989; Neelakantan et al., 1989; Pavlidis et al., 1991).

There are published reports of seasonal changes in the serum levels of thyroid hormones in fish (Burke and Leatherland, 1983; Cyr et al. 1988a; Leatherland and Sonstegard, 1980, 1981). However, studies that have examined seasonal changes in the plasma levels of thyroid hormones in teleosts are limited to a small number of species, mostly salmonids (Eales and Fletcher, 1982; Pickering and Christie, 1981). The results of these studies 
vary considerably by species. In fish species, circulating levels of thyroid hormones and/or thyroid activity are influenced by gonadal steroids (Cyr et al., 1988b; MacLatchy and Eales, 1988), which show circannual rhythms in their secretions closely related to breeding cycle and seasonal variations in ambient temperature (Chakraborti and Bhattacharya, 1984; Cyr et al., 1988a; Lamba et al., 1983). Furthermore, the reproductive cycle of fish has been the object of several studies in temperate zones (Hatakeyama and Akiyama, 2007; Pinillos et al., 2003; Prat et al., 1990). Comparatively little information is available for tropical and subtropical species (Bhattacharya et al., 2005; Chakraborti and Bhattacharya, 1984). Changes in gonadal activity are reportedly influenced by temperature and photoperiod (Bhattacharya et al., 2005; Koya and Kamiya 2000; Rodriguez et al., 2001; Shimizu 2003). Reproductive characteristics have been reported for Clarias gariepinus in a temperate zone (Cek and Yilmaz, 2007; Yalcin et al., 2001). Cyclical changes in the gonads have also been examined in a few closely related species, including the Natal mountain catfish Amphilius natalensis (Marriott et al., 1997) and freshwater catfish Mystus montanus (Arockiaraj et al., 2004). However, it is important to mention that these studies did not extend over the course of an entire year, and no simultaneous observations were made of the levels of thyroid hormones and testicular activity. Thus, the objective of the present study is to examine the annual pattern of thyroid hormone levels and testicular activity in the male catfish C. gariepinus (Burchell) maintained under natural climatic conditions in Shillong, India. This report describes monthly changes in the plasma levels of thyroid hormones (thyroxine, $\mathrm{T}_{4}$; triiodothyronine, $\mathrm{T}_{3}$ ) and testicular activity with particular reference to water temperature and natural day-length/photoperiod.

\section{Materials and Methods}

\subsection{Fish, experimental design and sampling}

All experiments were conducted on the adult male, Clarias gariepinus that breed in India during monsoon, and live in shallow rivers, ponds and muddy places. C. gariepinus can survive in low water levels with little oxygen. Specimens (body weight: 90-100 g; body length: $23-27 \mathrm{~cm}$ ) were purchased from the local fish suppliers. Fish were maintained in clear plastic tubs and acclimatized at least for 15 days in the laboratory under natural climatic conditions at Shillong $\left(25^{\circ} 30^{\prime} \mathrm{N}, 91^{\circ} 52^{\prime} \mathrm{E}\right.$; $1450 \mathrm{~m}$ ASL: minimum water temperature varied from $4-6^{\circ} \mathrm{C}$ and maximum water temperature varied from $23-25^{\circ} \mathrm{C}$ ). During acclimatization, the fish were fed daily ad libitum with minced earthworms and commercial fish feed (Tokyu). The water was changed every day. The water temperature was recorded daily, and the monthly average of the natural day-length (photoperiod) of Shillong was taken from the Central Meteorological Department in Meghalaya.

After acclimatization, blood samples and testes were collected from the fish regularly on the 14th/15th day of each month at an interval of 30 days throughout the year. The sampling was performed at 11:00 AM and was consistent throughout the experiment. To collect blood samples, we removed 4 fish from each group by a hand net and weighed them. Blood samples were collected from the postcaudal region in numbered heparinized centrifuge tubes. Simultaneously, testes were collected, weighed, and fixed in Bouin's fluid for histological study. Body and testes mass of each fish were used for calculating the gonadosomatic index (gonad mass x 100/total body mass). To obtain plasma, we centrifuged the blood samples for $15 \mathrm{~min}$ at $3000 \mathrm{xg}$ by using a REMI (Model R23) centrifuge, separated the plasma, and stored it at $-10^{\circ} \mathrm{C}$ in a refrigerator for the measurement of $\mathrm{T}_{4}$ and $\mathrm{T}_{3}$ concentrations.

\subsection{Measurement of plasma levels of thyroxine $\left(T_{4}\right)$ and triidothyronine $\left(T_{3}\right)$}

The plasma levels of $T_{4}$ and $T_{3}$ were measured with the help of radioimmunoassay kits RIAK5/5A for $T_{4}$ (sensitivity $0.625 \mathrm{ng} / \mathrm{ml}$, based on $93.67 \% \mathrm{~B} / \mathrm{Bo}$ intercept) and RIAK $4 / 4 \mathrm{~A}$ for $\mathrm{T}_{3}$ (sensitivity $0.0375 \mathrm{ng} / \mathrm{ml}$, based on $90.77 \%$ B/Bo intercept). Radioimmunoassay kits were obtained from the Division of Radiopharmaceutical Operations, Board of Radiation and Isotope Technology (BRIT), Mumbai. Radioimmunoassay (RIA) for $\mathrm{T}_{4}$ and $\mathrm{T}_{3}$ were conducted following the manufacturer's protocols with slight modifications where the hormone-free serum was replaced by hormone-free fish plasma (Gupta and Premabati, 2002). The RIA was validated using hormone-free fish plasma and different concentrations of standard solutions of $T_{3}($ range, $0.0375-2.4 \mathrm{ng} / \mathrm{ml})$ and $\mathrm{T}_{4}$ (range, $0.625-20 \mathrm{ng} / \mathrm{ml}$ ). The hormone-free fish plasma used in the assay was prepared by two cycles of the addition of dextran-coated charcoal to the pooled fish plasma, continuous stirring for 6 hours and centrifugation. Polyethylene glycol (PEG) solutions (12\% for $\mathrm{T}_{3}$ and $22 \%$ for $\left.\mathrm{T}_{4}\right)$ were used to separate the bound and free fractions of $\mathrm{T}_{4}$ and $\mathrm{T}_{3}$ in their respective RIA. The intra- and inter-assay variations were found to be, on average, less than $3.5 \%$ and $6.5 \%$ for $\mathrm{T}_{3}$ and $\mathrm{T}_{4}$, respectively. The radioactivity in the bound fraction was counted with the help of a well-type gamma counter (Electronic Corporation of India, Hyderabad). The concentrations of total $\mathrm{T}_{4}$ and total $\mathrm{T}_{3}$ were expressed as $\mathrm{ng} / \mathrm{ml}$ of plasma. 


\subsection{Histological study of testes}

After the testes had been in the fixative for 24-48 hours, they were removed from the fixative and were washed for 24 hours with running water. This was followed by a dehydration period of 20 minutes in each of $30 \%, 50 \%$, $70 \%, 90 \%$, and $90 \%$ and twice in a $100 \%$ ethanol range. After the dehydration process, the tissue was cleared in xylene and then embedded in paraffin wax. The hardened blocks were trimmed, mounted on tissue chucks and sectioned on a microtome into $6 \mu \mathrm{m}$ sections. Selected sections were mounted on clean glass slides, floated and stretched on a hot-plate and placed on a warming tray to dry and adhere. After dewaxing in xylene, the sections were hydrated in decreasing grades of ethanol and then stained with hematoxylin. After washing excess of hematoxylin, the sections were dehydrated in increasing grades of ethanol and stained with eosin. The stained sections were then further dehydrated, cleared in xylene and mounted with cover slips using DPX. The sections were examined under Zeiss Microscope and photographed.

\subsection{Statistical analyses}

The data were statistically analyzed with the help of analysis of variance (ANOVA). A probability of $\mathrm{P}<0.05$ was considered as significant.

\section{Results}

\subsection{Seasonal variations in the plasma levels of $T_{4}$ and $T_{3}$}

The data are presented in Figure 2. Seasonal variations were observed in the plasma levels of both $\mathrm{T}_{4}$ and $\mathrm{T}_{3}$ in male $C$. gariepinus. The plasma levels of $\mathrm{T}_{4}$ were low in January (winter), increased gradually beginning in March, and reached a peak in July (summer). Thereafter, the plasma levels of $T_{4}$ declined gradually to their minimum in January. There was a significant increase from the preceding months in the plasma levels of $\mathrm{T}_{4}$ in fish sampled during March, June, and July. By September and November, the plasma levels of $T_{4}$ had fallen significantly compared to the preceding months. As was the case for $T_{4}$ levels, the plasma levels of $T_{3}$ were also low in January and increased gradually to their highest levels in June (summer). Thereafter, the plasma levels of $\mathrm{T}_{3}$ declined gradually, reaching their lowest level in January. The plasma levels of $\mathrm{T}_{3}$ increased significantly from the preceding months in March and June. Furthermore, there was a significant decrease from the preceding months in the plasma levels of $\mathrm{T}_{3}$ in fish sampled during September, November, and January. Regression analysis indicated a positive correlation between water temperature and the plasma levels of $\mathrm{T}_{4}(r=0.92)$ and $\mathrm{T}_{3}$ $(r=0.85)$, as well as between natural day-length/photoperiod and the plasma levels of $\mathrm{T}_{4}(r=0.91)$ and $\mathrm{T}_{3}(r=$ 0.87) (Figure 1).

\subsection{Seasonal variations in the gonadosomatic index (GSI)}

The GSI was low in January and February, increased gradually in March and April (spring). The GSI was highest in May, remained high in June, and thereafter declined gradually to its minimum value in January. The GSI in April and May increased significantly from the preceding months (Figure 3). Regression analysis indicated a positive correlation between water temperature and the GSI $(r=0.86)$ as well as between photoperiod and the GSI $(r=0.90)$ (Figure 1).

\subsection{Seasonal variations in the histology of the testes}

Histological observations revealed the presence of only spermatogonia in the testes in January (Plate A). In February, the seminiferous tubules of the testes contained spermatogonia and spermatocytes (Plate B). In March, these tubules increased in diameter and contained lower numbers of spermatogonia, spermatocytes and small populations of spermatozoa (Plate C). Whereas the number of mature spermatozoa increased in April, the number of spermatogonia decreased considerably and the seminiferous tubules were much enlarged, indicating active spermatogenesis (Plate D). In May and June, the seminiferous tubules were filled with mature spermatozoa and smaller numbers of spermatogonia and spermatocytes (Plates E and F). In July, the tubules were filled with spermatozoa (Plate G). However, the spermatozoa declined gradually in August and September (Plates H and I). In October and November (autumn), there was marked reduction in the diameter of the seminiferous tubules, and the tubules contained degenerating spermatozoa along with a few scattered spermatogonia (Plates $\mathrm{J}$ and $\mathrm{K}$ ). In December, the seminiferous tubules contained small numbers of spermatogonia, but residual spermatozoa were also still observed and there was a reduction in the diameter of the tubules (Plate L).

\section{Discussion}

Seasonal variations in the levels of thyroid hormones have been reported in a number of temperate zone fish species, such as Oncorhynchus masou, Salmo gairdneri, Pseudopleuronectes americanus, Dentex dentex, and 
Gadus morhua (Bau and Parent, 2000; Comeau et al., 2000; Cyr et al., 1988a, 1998; Eales and Fletcher, 1982; Leloup and De-Luze, 1985; Nishikawa et al., 1979; Pavlidis et al., 2000; Sower et al., 1992; Stryjek-Kaminska et al., 1988). Seasonal variations in the levels of thyroid hormones have also been reported in the tropical freshwater perch Anabas testudineus (Chakraborti and Bhattacharya, 1984). However, these studies were performed during a particular season of the year, and no simultaneous observations were made of the seasonal changes in the circulating levels of thyroid hormones and testicular activity.

In the present results, the plasma levels of thyroid hormones and testicular activity in C. gariepinus exhibit prominent and parallel seasonal rhythms. The plasma levels of thyroid hormones and testicular activity (as indicated by the GSI and histology) were lowest during the winter months when the water temperature was low and natural day-length was short. Thereafter, the hormone levels as well as the testicular activity increased gradually with the gradual increase in water temperature and day-length during the spring season. The plasma levels of thyroid hormones and testicular activity were highest during the summer months when the water temperature was comparatively higher and the natural day-length longer. The patterns of seasonal change in the levels of the thyroid hormones as well as testicular activity in C. gariepinus were observed to be similar to those of water temperature and natural day-length. There was also a significant positive correlation between the plasma levels of the thyroid hormones and both water temperature and day-length (Figure 1). These results indicate that prominent seasonal rhythms in the levels of thyroid hormones and testicular activity in $C$. gariepinus coincide with seasonal changes in water temperature and day-length. Although the possibility of completely dependent or independent control of temperature and photoperiod on the plasma levels of thyroid hormones and testicular activity cannot be discounted, their distinct and parallel seasonal rhythm is consistent with previous reports that environmental temperature and photoperiod synchronize and/or regulate thyroid and reproductive seasonality in the fish. Furthermore, the plasma levels of the thyroid hormones showed a similar pattern of seasonal change as testicular activity/maturation in C. gariepinus. Several reports have suggested that thyroid hormones may be required to initiate gonadal development and maintain the active reproductive state of fish (Sullivan et al., 1995; Swapna and Senthilkumaran, 2007; Tagawa et al., 1994). Therefore, the present observation of the similarity in the pattern of seasonal change in the plasma level of thyroid hormones and testicular maturation seems to suggest that thyroid hormones are involved in maintaining the active reproductive state of C. gariepinus. However, further study is required to determine the causal relationships between the seasonally varying thyroid hormones and the testicular activity systems in this fish in a tropical/subtropical region. Furthermore, it has been reported that the metabolic rate and the rate of respiration of several vital tissues of fish increase and decrease with reproductive activity over the annual time scale (Lynshiang, 1998) and that thyroid hormones reportedly stimulate the rate of respiration/oxidative metabolism in several fish species (Eales and Maclatchy, 1989; Gupta and Thapliyal, 1991; Lynshiang and Gupta, 2000). It thus seems that the observed increase in the levels of thyroid hormones during the spring and summer seasons in C. gariepinus ensures an adequate energy supply for meeting the increased energy demands associated with reproductive behavior and associated activities.

Little information is available on the reproductive cycle of C. gariepinus in tropical/subtropical zones or in temperate regions, and none of the existing studies have described testicular maturation over each month of the year. Some reproductive characteristics of $C$. gariepinus in temperate regions have been reported under natural conditions (Yalcin et al., 2001) as well as under laboratory conditions (Cek and Yilmaz, 2007). However, it is important to mention that these studies were not conducted over the course of an entire year and hence could not delineate the pattern in the annual rhythm of the testicular activity/maturation of the fish. Therefore, here we have presented findings on the testicular activity/maturation of C. gariepinus in a tropical/subtropical region for each month of the year. Observations on GSI and testicular histology revealed a distinct seasonal variation in the testicular activity of $C$. gariepinus over the annual time scale. We found that increasing testicular activity of the fish coincided with increasing water temperature and natural day-length. Spermatogenesis started to increase in February and March. Mature spermatozoa were found from April through September, and a rapid decline in testicular activity was observed from October through November (autumn). Quiescent testes were found in December and January (winter). The gradual increase in the GSI in March corresponded to the commencement of basal spermatogenesis. Thus, the prominent and gradual increase in the GSI from March to its peak in May corresponded to the enlargement of testicular tubules due to active spermatogenesis. Furthermore, the seminiferous tubules increased in diameter from March to September. It is important to mention that mature spermatozoa were observed in the seminiferous tubule from April (water temperature, above $20^{\circ} \mathrm{C}$; day-length, more than $12 \mathrm{~h}$ ) to September (water temperature, above $21.5^{\circ} \mathrm{C}$; day-length, more than $12.23 \mathrm{~h}$ ). These results indicate that the breeding phase of the fish (April to September) is prolonged in tropical/subtropical regions. Regression analysis also revealed a significant positive correlation between the GSI and both water temperature 
and day-length (Figure 1). Thus, water temperature and day-length seem to play an important role in shaping the annual breeding cycle as well as regulating testicular activity in C. gariepinus. Temperature and photoperiod have also been reported to regulate seasonal changes in the reproductive functions of Catla catla, Fundulus heteroclitus, Dicentrarchus labrax (Bhattacharya et al. 2005; Dey et al., 2005; Rodriguez et al., 2001; Shimizu, 2003), Pagrus auratus (Bloch and Schneider) (Scott and Pankhurst, 1992), and Heteropneustes fossilis (Lamba et al., 1983). Furthermore, it has also been reported that increasing water temperature and day-length were favorable for gonadal development in Labeo rohita (Singh et al., 2005). These reports, when taken together with the present findings, indicate that seasonal changes in the environmental water temperature and natural day-length are primary cues for altering testicular activity and play major roles in the regulation of breeding/reproduction of the fish. It is a well-established fact that testosterone and 11-ketotestosterone are important for regulating spermatogenesis in fish (Borg, 1994; Cavaco, 2005; Cavaco et al., 1998; Dubious et al., 2001; Goos et al., 1986; Miura et al., 1991). It has been shown that the plasma levels of testosterone and 11-ketotestosterone are low during the resting/non-reproductive period and high during the nesting/maturation period (Gazola and Borella, 1997; Sisneros et al., 2004). Furthermore, seasonal changes in plasma and serum gonadal steroid hormone levels have been documented in a number of fish species (Dye et al., 1986; Harmin et al., 1995; Liley et al., 1986; Mayer et al., 1990; Pavlidis et al., 1994; Prat et al., 1990; Scott and Sumpter, 1989; Scott et al., 1980; Thorarensen et al., 1995). Therefore, there is a strong possibility that the observed prominent seasonal changes in testicular activity might be related to seasonal variations in the sex steroids of $C$. gariepinus. Further investigations into the monthly concentrations of sex steroids in C. gariepinus would shed more light on seasonal changes in testicular activity/maturation.

\section{Conclusion}

In conclusion, male $C$. gariepinus displayed distinct seasonal changes in plasma levels of thyroid hormones and testicular activity over the annual cycle. The increase in plasma levels of thyroid hormones coincided with an increase in the testicular activity of the fish. Although the possibility of completely dependent and/or independent thyroid control of testicular activity cannot be discounted and further study on C. gariepinus is needed, the distinct and parallel seasonal rhythms seen here are consistent with previous reports that thyroid hormones are progonadal. The patterns of seasonal change in the levels of thyroid hormones as well as testicular activity were similar to those in water temperature and natural day-length. The breeding phase of the fish also seems to be timed to favorable water temperature $\left(>20^{\circ} \mathrm{C}\right)$ and natural day-length $(>12 \mathrm{~h})$.

\section{Acknowledgements}

Financial assistance in the form of Rajiv Gandhi National Fellowship from the Ministry of Tribal Affairs, Government of India is gratefully acknowledged.

\section{References}

Andrade, P. M., \& Braga, F. M. (2005). Reproductive seasonality of fishes from a lotic stretch of the Grande River, high Paraná river basin, Brazil. Brazilian Journal of Biology, 65, 387-394.

Arockiaraj, A. J., Haniffa, M. A., Seetharaman, S., \& Singh, S. (2004). Cyclic changes in gonadal maturation and histological observations of threatened freshwater catfish ÒNarikeliruÓ Mystus montanus (Jerdon, 1849). Acta Ichthyologoca et Piscatoria, 34, 253-266.

Bau, F., \& Parent, J. P. (2000). Seasonal variations of thyroid hormone levels in wild fish. Comptes Rendus de l Academie des Sciences. Serie - III, 323, 365-372.

Bhattacharya, S., Dey, R., \& Maitra, S. K. (2005). Photoperiodic regulation of annual testicular events in the Indian major carp, Catla catla. Acta Zoologica, 86, 71-79.

Borg, B. (1994). Androgens in teleost fishes. Comparative Biochemistry and Physiology Part C Pharmacology, Toxicology and Endocrinology, 109, 219-245.

Burke. M., \& Leatherland, J. F. (1983). Seasonal changes in serum thyroid hormone levels of the feral brown bullhead, Ictalurus nebulosus Lesueur. Journal of Fish Biology, 23, 585-593.

Cavaco, J. E. (2005). Sex steroids and spermatogenesis in the African catfish (Clarias gariepinus). Arch Andrologia, 51, 99-107.

Cavaco, J. E., Vilrokx, C., Trudeau, V. L., Schulz, R. W., \& Goos, H. J. (1998). Sex steroids and the initiation of puberty in male African catfish (Clarias gariepinus). American Journal of Physiology, 275, R1793-1802.

Cek, S., \& Yilmaz, E. (2007). Gonad Development and Sex Ratio of Sharptooth Catfish (Clarias gariepinus Burchell, 1822) Cultured under Laboratory Conditions. Turkish Journal of Zoology, 31, 35-46. 
Chakraborti, P., \& Bhattacharya, S. (1984). Plasma thyroxine levels in freshwater Perch: influence of season, gonadotropins, and gonadal hormones. General and Comparative Endocrinology, 53, 179-186.

Comeau, L.A., Campana, S.E., Hanson, J.M., \& Chouinard, G.A. (2000). Seasonal changes of thyroid hormones in field-collected Atlantic cod in relation to condition indices, water temperature and photoperiod. Journal of Fish Biology, 57, 571-588.

Cyr, D. G., Bromage, N. R., Duston, J., \& Eales, J. G. (1988a). Seasonal patterns in serum of thyroid hormones and sex steroids in relation to photoperiod-induced changes in spawning time in Rainbow trout, Salmo gairdneri. General and Comparative Endocrinology, 69, 217-225.

Cyr, D. G., Idler, D. R., Audet, C., McLeese, J. M., \& Eales, J. G. (1998). Effects of long-term temperature acclimation on thyroid hormone deiodinase function, plasma thyroid hormone levels, growth and reproductive status of male Atlantic cod, Gadus morhua. General and Comparative Endocrinology, 109, 24-36.

Cyr, D. G., MacLatchy, D. L., \& Eales, J. G. (1988b). The influence of short-term 17 beta-estradiol treatment on plasma $\mathrm{T}_{3}$ levels and in vitro hepatic $\mathrm{T}_{4} 5$ '-monodeiodinase activity in immature Rainbow trout, Salmo gairdneri. General and Comparative Endocrinology, 69, 431-438.

Dey, R., Bhattacharya, S., \& Maitra, S. K. (2005). Importance of photoperiods in the regulation of ovarian activities in Indian major carp Catla catla in an annual cycle. Journal of Biological Rhythms, 20, 145-158.

Dubois, E. A., Slob, S., Zandbergen, M. A., Peute, J., \& Goos, H. J. (2001). Gonadal steroids and the maturation of the species-specific gonadotropin-releasing hormone system in brain and pituitary of the male African catfish (Clarias gariepinus). Comparative Biochemistry and Physiology Part B Biochemistry and Molecular Biology, 129, 381-387.

Dye, H. M., Sumpter, J. P., Fagerlund, U. H. M., \& Donaldson, E. M. (1986). Changes in reproductive parameters during the spawning migration of pink salmon, Oncorhynchus gorbuscha (Walbaum). Journal of Fish Biology, 29, 167-176.

Eales, J. G. (2006). Modes of action and physiological effects of thyroid hormones in fish. In: M. Reinecke, G. Zaccone \& B.G. Kapoor (Eds.), Fish Endocrinology (pp. 768-808). Science Publishers, Enfield, NH, USA.

Eales, J. G., \& Fletcher, G. L. (1982). Circannual cycle of thyroid hormones in plasma of winter flounder (Pseudopleuronectes americanus Walbaum). Canadian Journal Zoology, 60, 304-309.

Eales, J. G., \& Maclatchy, D. L. (1989). The relationship between $T_{3}$ production and energy balance in salmonids and other teleosts. Fish Physiology and Biochemistry, 7, 289-293.

Gazola, R., \& Borella, M. I. (1997). Plasma testosterone and 11-ketotestosterone levels of male pacu piaractus mesopotamicus (Cypriniformes, Characidae). Brazilian Journal of Medical and Biological Research, 30, 1485-1487.

Goos, H. J. T., de Leeuw, R., Cook, H., \& van Oordt, P. G. W. J. (1986). Gonadotropin-releasing hormone (GRH) bioactivity in the brain of immature rainbow trout, Salmo gairdneri: the effect of testosterone. General and Comparative Endocrinology, 64, 80-84.

Gupta, B. B. P., \& Premabati, Y. (2002). Differential effects of melatonin on plasma levels of thyroxine and triiodothyronine levels in the air-breathing fish, Clarias gariepinus during breeding and quiescent periods. General and Comparative Endocrinology, 129, 146-151.

Gupta, B. B. P., \& Thapliyal, J. P. (1991). Endocrine regulation of the oxidative metabolism in poikilothermic vertebrates. Zoological Science, 8, 625-634.

Harmin, S. A., Crim, L. W., \& Wiegand, M. D. (1995). Plasma sex steroid profiles and the seasonal reproductive cycle in male and female winter flounder, Pleuronectes americanus. Marine Biology, 121, 601-610.

Hatakeyama, R., \& Akiyama, N. (2007). Annual reproductive cycle of a bitterling, Tanakia tanago, reared in an outdoor tank. Zoological Science, 24, 614-622.

Imbert, H., Arrowsmith, R., Dufour, S., \& Elie, P. (2008). Relationships between locomotor behavior, morphometric characters and thyroid hormone levels give evidence of stage-dependent mechanisms in European eel upstream migration. Hormone and Behavior, 53, 69-81.

Iwata, M. (1995). Downstream migratory behavior of salmonids and its relationship with cortisol and thyroid hormones: A review. Aquaculture, 135,131-139. 
Klaren, P. H., Guzman, J. M., Mancera, J. M., Geven, E. J., \& Flik, G. (2005). The involvement of thyroid hormone metabolism in gilthead sea bream (Sparus auratus) osmoregulation. Annals of the New York Academy of Sciences, 1040, 360-362.

Koya, Y., \& Kamiya, E. (2000). Environmental regulation of annual reproductive cycle in the mosquito fish, Gambusia affinis. Journal of Experimental Zoolology, 286, 204-211.

Lamba, V. J., Goswami, S. V., \& Sundararaj, B. I. (1983). Circannual and circadian variations in plasma levels of steroids (cortisol, estradiol-17 beta, estrone, and testosterone) correlated with the annual gonadal cycle in the catfish, Heteropneustes fossilis (Bloch). General and Comparative Endocrinology, 50, 205-225.

Leatherland, J. F., \& Sonstegard, R. A. (1980). Seasonal changes in thyroid hyperplasia, serum thyroid hormone and lipid concentration and pituitary gland structure in Lake Ontario coho salmon (Oncorhynchus kisutch), and a comparison with coho salmon from Lakes Machigan and Erie. Journal of Fish Biology, 16, 539-562.

Leatherland, J. F., \& Sonstegard, R. A. (1981). Thyroid dysfunction in Great Lakes coho salmon, Oncorhynchus kisutch (Walbaum): seasonal and interlake differences in serum $\mathrm{T}_{3}$ uptake and serum total and free $\mathrm{T}_{4}$ and $\mathrm{T}_{3}$ levels. Journal of Fish Biology, 4, 413-423.

Leloup, J., \& De Luze, A. (1985). Environmental effects of temperature and salinity in teleost fishes. In: B. K. Follett, S. Ishii \& A. Chandola (Eds.), The Endocrine System and the Environment (pp. 23-32). Japan Sci. Soc. Press, Tokyo/Springer-Verlag, Berlin.

Liley, N. R., Breton, B., Fostier, A., \& Tan, E. S. P. (1986). Endocrine changes associated with spawning behavior and social stimuli in a wild population of rainbow trout (Salmo gairdneri): I. Male. General and Comparative Endocrinology, 62, 145-156.

Lynshiang, D. S. (1998). Role of hormones in regulation of the oxidative metabolism in fish. Ph. D. Thesis, North-Eastern Hill University, Shillong, India.

Lynshiang, D. S., \& Gupta, B. B. P. (2000). Role of thyroidal and testicular hormones in regulation of tissue respiration in the male air-breathing fish, Clarias batrachus. Indian Journal of Experimental Biology, 38, 705-712.

MacLatchy, D. L., \& Eales, J. G. (1988). Short term treatment with testosterone increases plasma 3,5,3'-triiodo-L-thyronine and hepatic L-thyroxine 5'-monodeiodinase levels in Arctic charr, Salvelinus alpinus. General and Comparative Endocrinology, 71, 10-16.

Malhotra, Y. R., Jyoti, M. K., \& Gupta, K. (1989). Reproductive cycles of freshwater fishes. In: S. K. Saidapur (Ed.), Reproductive Cycles of Indian Vertabrates (pp. 58-105). Allied Publishers, New Delhi.

Matty, A. J. (1985). The thyroid gland. In: Fish Endocrinology (pp. 54-83). Croom Helm, London.

Marriott, M. S., Booth, A. J., \& Skelton, P. H. (1997). Reproductive and feeding biology of the Natal mountain catfish, Amphilius natalensis (Siluriformes: Amphiliidae). Environmental Biology of Fish, 49, 461- 470.

Mayer, I., Borg, B., \& Schulz, R. (1990). Seasonal changes in and effect of castration/androgen replacement on the plasma levels of five androgens in the male three-spined stickleback, Gasterosteus aculeatus L. General and Comparative Endocrinology, 791, 23-30.

Miura, T., Yamauchi, K., Takahashi, H., \& Nagahama, Y. (1991). Hormonal induction of all stages of spermatogenesis in vitro in the male Japanese eel (Anguilla japonica). Proceeding of National Academic of Science USA, 88, 5774-5778.

Neelakantan, B., Kusuma, N., \& Bhat, U. G. (1989). Reproductive cycles of marine fishes. In: S. K. Saidapur, (Ed.), Reproductive Cycles of Indian Vertabrates (pp. 106-165). Allied Publishers, New Delhi.

Nishikawa, K., Hirashima, T., Suzuki, S., \& Suzuki, M. (1979). Changes in circulating L-thyroxine and L-triiodothyronine of the Masu salmon, Oncorhynchus masou accompanying the smoltification, measured by radioimmunoassay. Endocrinology Japan, 26, 731-735.

Ojima, D., \& Iwata, M. (2007). The relationship between thyroxine surge and onset of downstream migration in Chum salmon, Oncorhynchus keta fry. Aquaculture, 272, 185-193.

Pavlidis, M., Dessypris, A., \& Christofidis, I. (1991). Seasonal fluctuations in plasma thyroid hormones, in two strains of Rainbow trout (Oncorhynchus mykiss), during the first and second reproductive cycle: relation with their photoperiodically altered spawning time. Aquaculture, 99, 365-385. 
Pavlidis, M., Dimitriou, D., \& Dessypris, A. (1994). Testosterone and 17B-estradiol plasma fluctuations throughout spawning period in male and female rainbow trout, Oncorhynchus mykiss (Walbaum), kept under several photoperiod regimes. Annales Zoologici Fennici, 31, 319-327.

Pavlidis. M., Greenwood, L., Mourot, B., Kokkari, C., Le Menn, F., Divanach, P., \& Scott, A. P. (2000). Seasonal variations and maturity stages in relation to differences in serum levels of gonadal steroids, vitellogenin and thyroid hormones in the common Dentex (Dentex dentex). General and Comparative Endocrinology, 118, $14-25$.

Peter, M. C. S., \& Oommen, V. O. (1987). Effect of triiodo-L-thyronine on oxidative metabolism of a teleost, Anabas testudineus (Bloch). Journal of Reproductive Biology and Endocrinology, 7, 53-60.

Peter, M. C., Lock, R. A., \& Bonga, S. E. W. (2000). Evidence for an osmoregulatory role of thyroid hormones in the fresh water Masambique tilapia, Oreochromis mossambicus. General and Comparative Endocrinology, 120, 157-167.

Pickering, A. D., \& Christie, P. (1981). Changes in the concentrations of plasma cortisol and thyroxine during sexual maturation of the hatchery-reared brown trout, Salmo trutta. General and Comparative Endocrinology, 44, 487-496.

Pinillos, M. L., Delgado, M. J., \& Scott, A. P. (2003). Seasonal changes in plasma gonadal steroid concentrations and gonadal morphology of male and female tench (Tinca tinca, L.). Aquaculture, 34, 1181-1189.

Prat, F., Zanuy, S., Carrillo, M., de Mones, A., \& Fostier, A. (1990). Seasonal changes in plasma levels of gonadal steroids of sea bass, Dicentrarchus labrax L. General and Comparative Endocrinology, 78, 361-373.

Rodriguez, L., Begtashi, I., Zanuy, S., Shaw, M., \& Carrillo, M. (2001). Changes in plasma levels of reproductive hormones during first sexual maturation in European male sea bass (Dicentrarchus labrax L.) under artificial daylengths. Aquaculture, 202, 235-248.

Scott, A. P., \& Sumpter, J. P. (1989). Seasonal variations in testicular germ cell stages and in plasma concentrations of sex steroids in male rainbow trout (Salmo gairdneri) maturing at 2 years old. General and Comparative Endocrinology, 73, 46-58.

Scott, S.G., Pankhurst, N.W. 1992. Interannual variation in the reproductive cycle of the New Zealand snapper Pagrus auratus (Bloch \& Schneider) (Sparidae). Journal of Fish Biology, 41, 685-696.

Scott, A. P., Bye, V. J., Baynes, S. M., \& Springate, J. R. C. (1980). Seasonal variations in plasma concentrations of 11-ketotestosterone and testosterone in male rainbow trout, Salmo gairdnerii Richardson. Journal of Fish Biology, 17(5), 494-505.

Shimizu, A. (2003). Effect of photoperiod and temperature on gonadal activity and plasma steroid levels in a reared strain of the Mummichog (Fundulus heteroclitus) during different phases of its annual reproductive cycle. General and Comparative Endocrinology, 131, 310-324.

Singh, A. K., Kumar, A., Singh, I. J., \& Ram, R. N. (2005). Seasonal ovarian cycle in freshwater teleost, Labeo rohita (Ham.) in Tarai region of Uttaranchal. Journal of Environmental Biology, 26, 557-565.

Sisneros, J. A., Forlano, P. M., Knapp, R., \& Bass, A. H. (2004). Seasonal variation of steroid hormones levels in an intertidal-nesting fish, the vocal plainfin midshipman. Journal of Environmental Biology, 136, 101-116.

Sower, S. A., Karlson, K. H., \& Fawcett, R. S. (1992). Changes in plasma thyroxine, estradiol-17 $\beta$, and 17 $\alpha$, 20ß-dihydroxy-4-pregnen-3-one during smoltification of Coho salmon. Journal of Environmental Biology, 85, 278-285.

Stryjek-Kaminska, D., Loos, U., Maier, V., Ditschuneit, H. H., \& Pfeiffer, E. F. (1988). Seasonal variations of glucose and triiodothyronine concentrations in serum of carp (Cyprinus carpio L). Hormone and Metabolic Research, 20, 727-729.

Sullivan, C. V., Bernard, M. G., Hara, A., \& Dickhoff, W. W. (1995). Thyroid hormones in trout reproduction: Enhancement of gonadotropin-releasing hormone analogue and partially purified salmon gonadotropin-induced ovarian maturation in vivo and in vitro. Journal of Experimental Zoology, 250, 188-195.

Supriya, A., Raghuveer, K., Swapna, I., Rasheeda, M. K., Kobayashi, T., \& Nagahama, Y. (2005). Thyroid hormone modulation of ovarian recrudescence of air-breathing catfish Clarias gariepinus. Fish Physiology and Biochemistry, 31, 267-270. 
Swapna, I., \& Senthilkumaran' B. (2007). Thyroid hormones modulate the hypothalamo-hypophyseal-gonadal axis in teleosts: Molecular insights. Fish Physiology and Biochemistry, 33, 335-345.

Tagawa, M., Ogasawara, T., Sakamoto, T., Miura, T., Yamauchi, K., \& Hirano, T. (1994). Thyroid hormone concentrations in the gonads of wild chum salmon during maturation. Fish Physiology and Biochemistry, 13, 233-240.

Thorarensen, H., Knight, C., \& Davie, P. S. (1995). Seasonal changes in 11-ketotestosterone and relative ventricle mass in wild rainbow trout, Oncorhynchus mykiss. New Zealand Journal of Marine and Freshwater Research, 30, 397 - 402.

Volkoff, H., Wourms, J. P., Amsebury, E., \& Snelson, F. F. (1999). Structure of the thyroiod gland, serum thyroid hormones and the reproductive cycle of the Atlantic stingray, Dasyatis Sabina. Journal of Experimental Zoology, 284, 505-516.

Yalcin, S., Solak, K., \& Akyurt, I. (2001). Certain Reproductive Characteristics of the Catfish (Clarias gariepinus Burchell, 1822) Living in the River Asi, Turkey. Turkish Journal of Zoology, 25, 453-460.
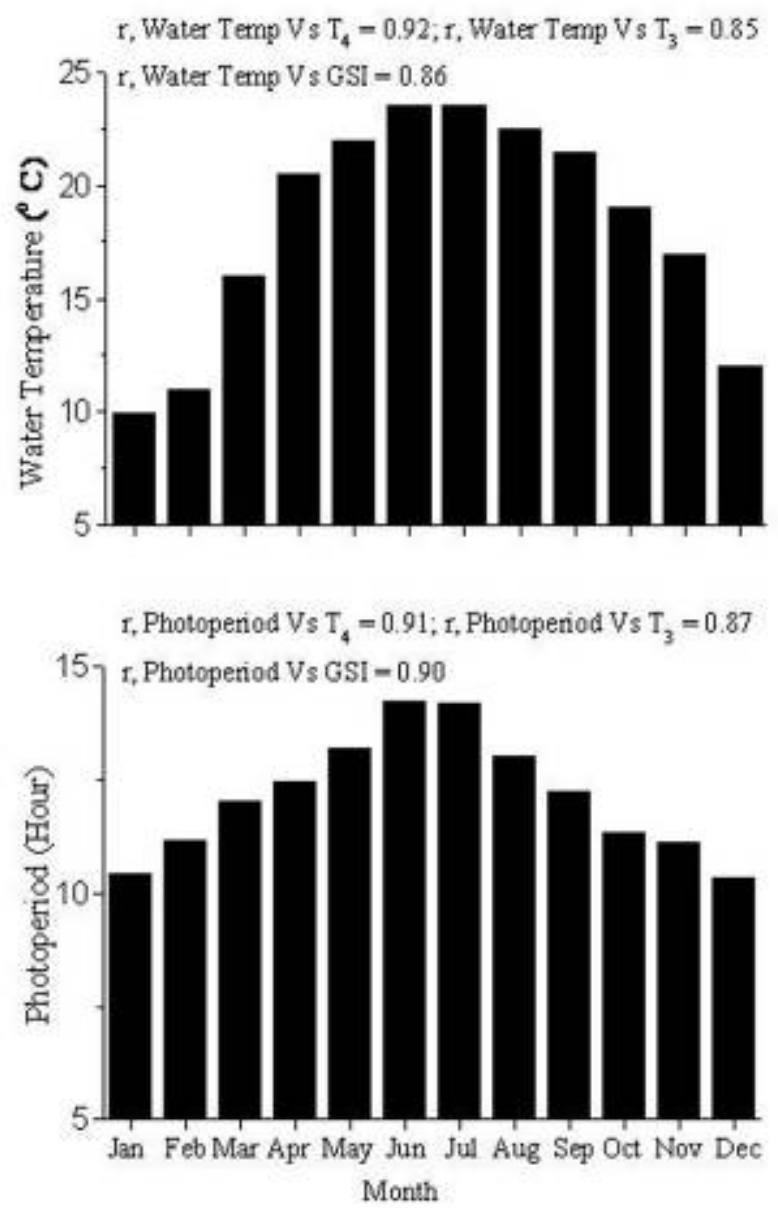

Figure 1. Monthly variations in water temperature and photoperiod 

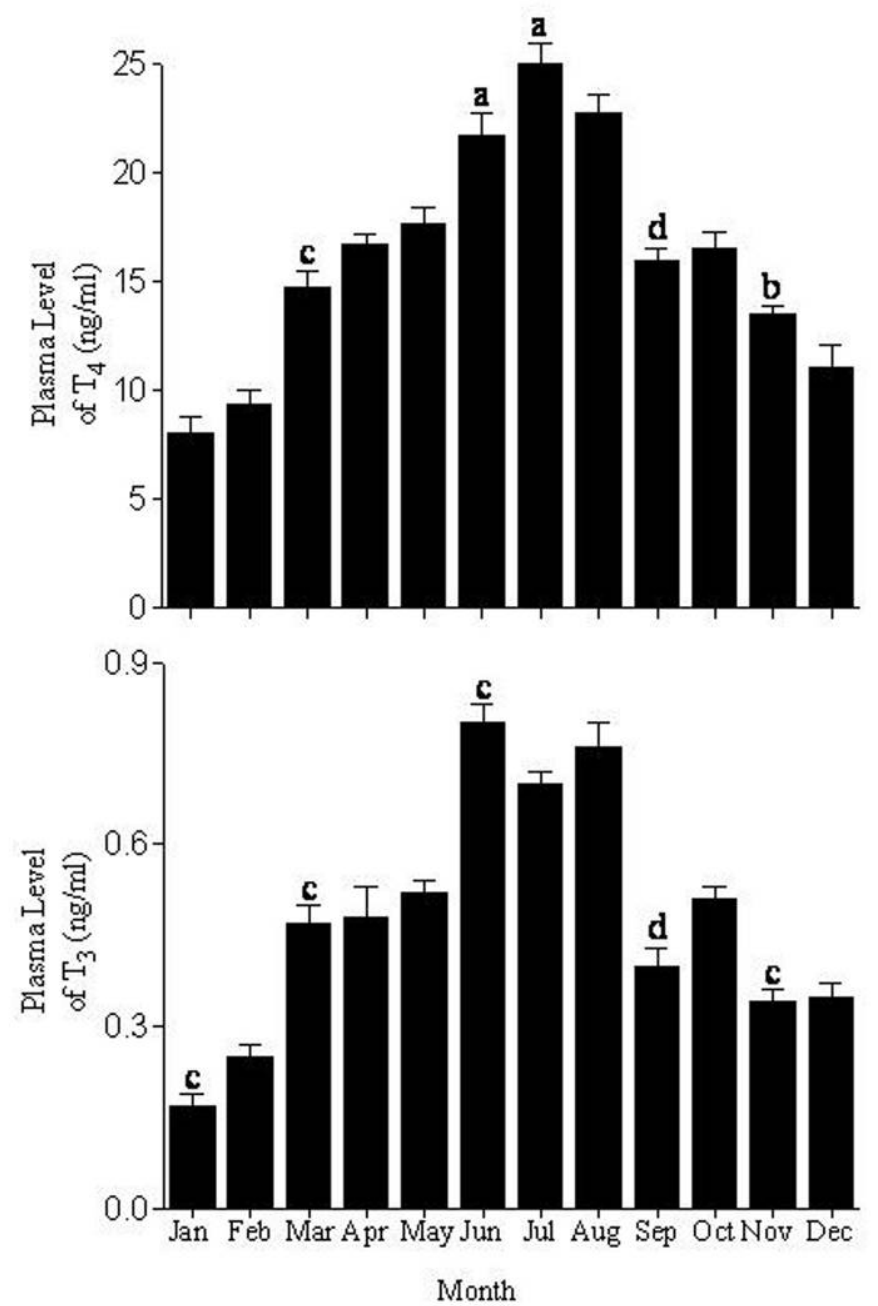

Figure 2. Monthly variations in the plasma levels of thyroid hormones thyroxine $\left(\mathrm{T}_{4}\right)$ and triiodothyronine $\left(\mathrm{T}_{3}\right)$. $\mathrm{T}_{4}$ and $\mathrm{T}_{3}$ values are expressed as mean \pm S.E.; $n=4$.

a, b, c, d Differs significantly from the preceding month: $P<0.05,0.02,0.01$, and 0.001 , respectively.

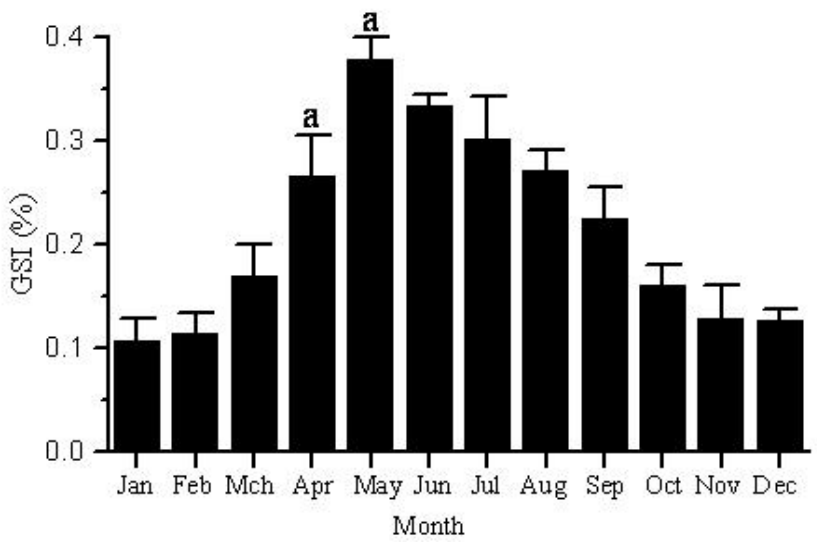

Figure 3. Monthly variations in the gonadosomatic index (GSI)

GSI values are expressed as mean \pm S.E.; $n=4$.

${ }^{a}$ Differs significantly from the preceding month: $P<0.05$. 

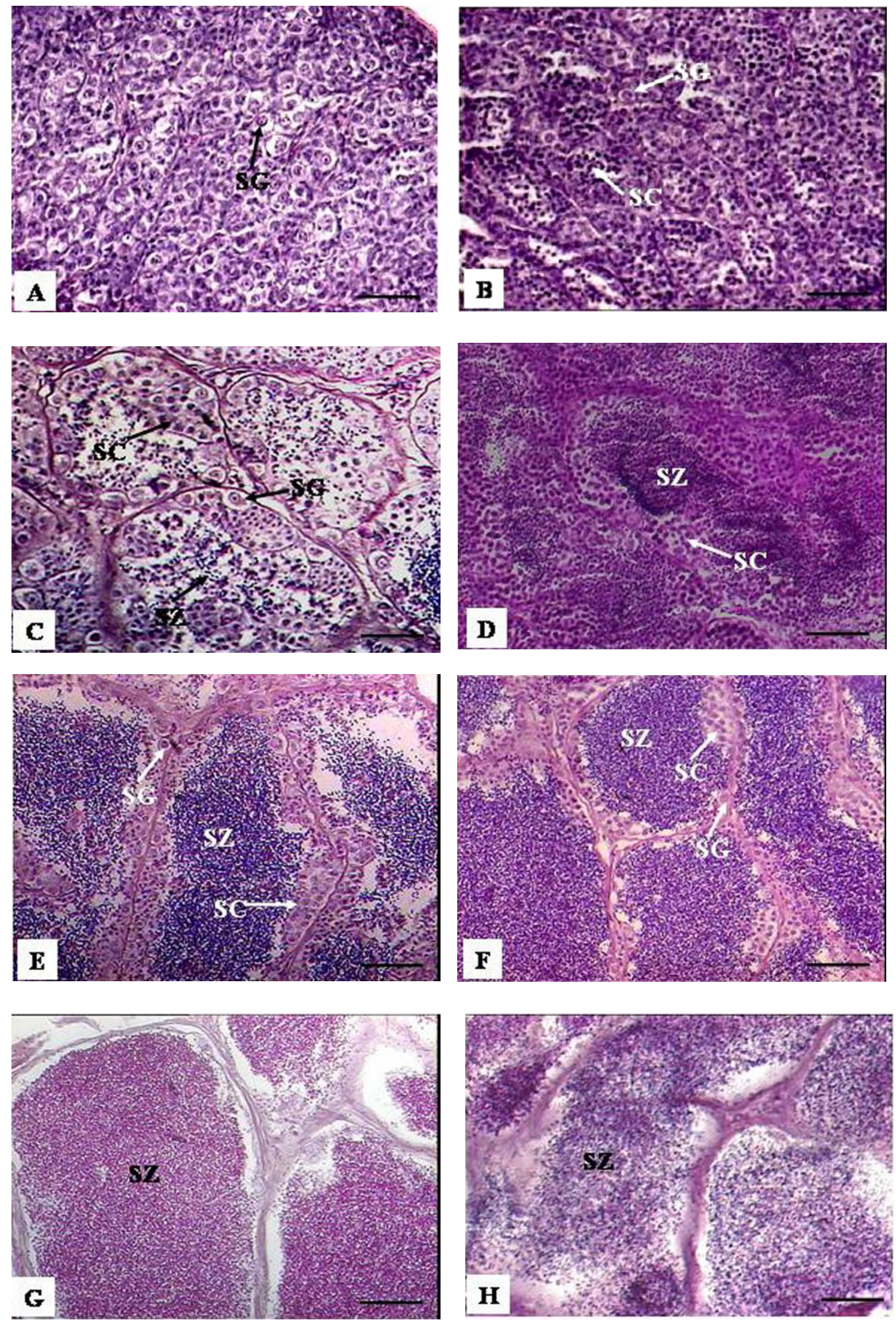

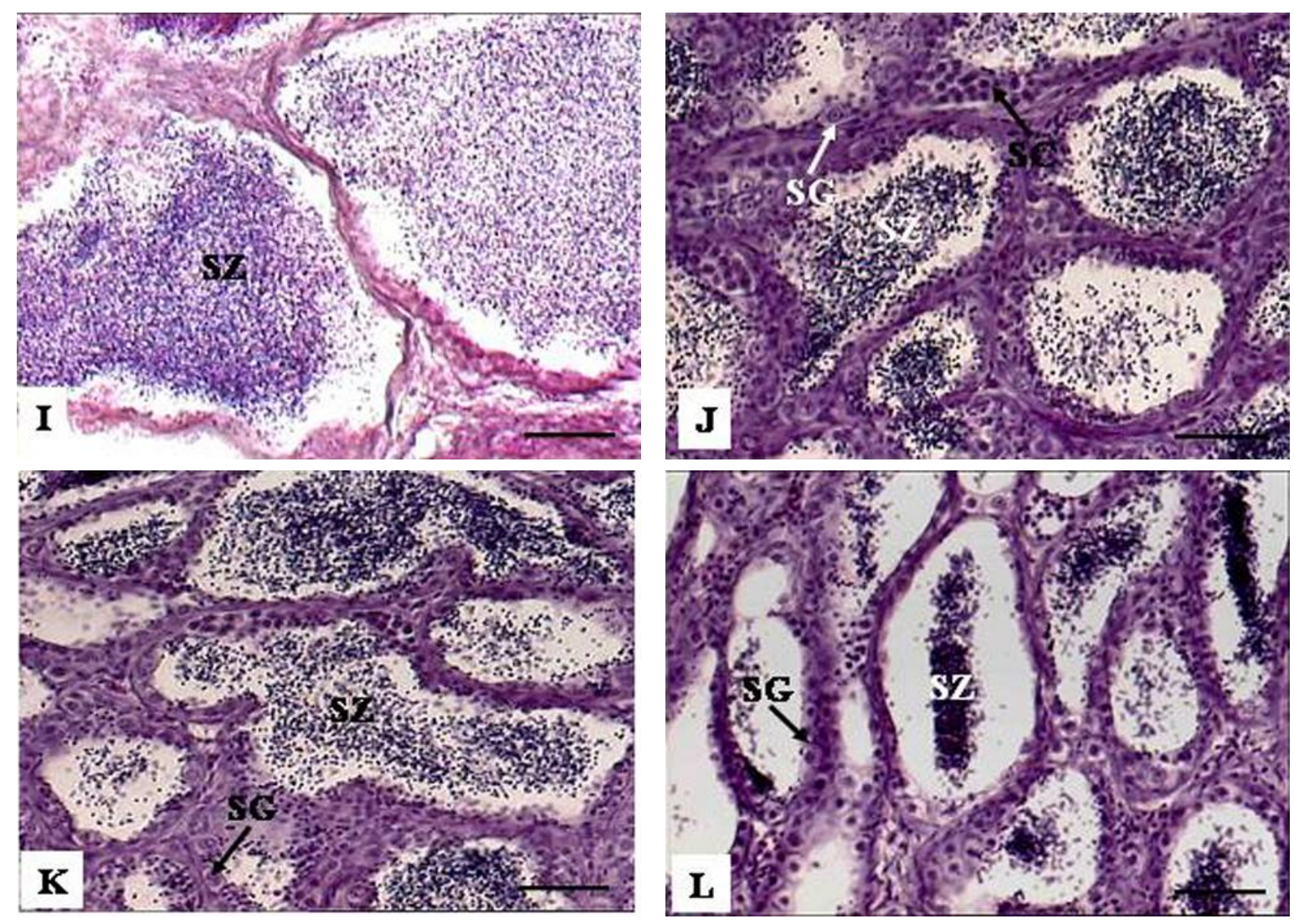

Plate (A-L) Monthly variations in the testicular histology of Clarias gariepinus.

(A) January, (B) February, (C) March, (D) April, (E) May, (F) June, (G) July, (H) August, (I) September, (J) October, (K) November, and (L) December. Bars $=100 \mu \mathrm{m}$. $\mathrm{SG}=$ spermatogonia; $\mathrm{SC}=$ spermatocytes, $\mathrm{SZ}=$ spermatozoa. 